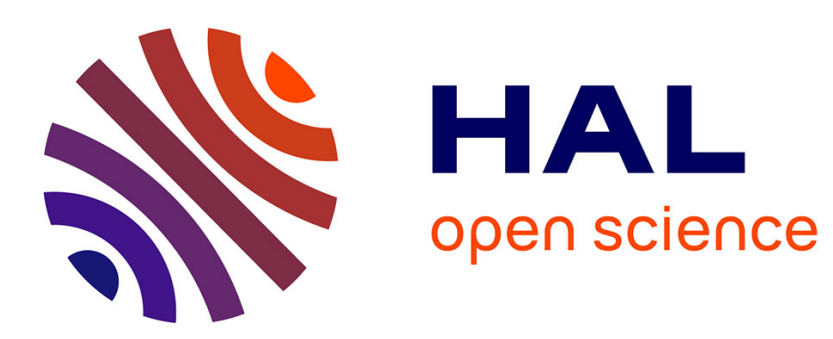

\title{
Multicriteria Decision Aid Tool for Third-Party Logistics Providers' Selection
}

\author{
Aicha Aguezzoul, Besoa Rabenasoloo, Anne-Marie Jolly-Desodt
}

\section{To cite this version:}

Aicha Aguezzoul, Besoa Rabenasoloo, Anne-Marie Jolly-Desodt. Multicriteria Decision Aid Tool for Third-Party Logistics Providers' Selection. International Conference Service Systems and Service Management (ICSSSM), Oct 2006, Troyes, France. pp.5. hal-00366524

\section{HAL Id: hal-00366524 https://hal.science/hal-00366524}

Submitted on 9 Mar 2009

HAL is a multi-disciplinary open access archive for the deposit and dissemination of scientific research documents, whether they are published or not. The documents may come from teaching and research institutions in France or abroad, or from public or private research centers.
L'archive ouverte pluridisciplinaire HAL, est destinée au dépôt et à la diffusion de documents scientifiques de niveau recherche, publiés ou non, émanant des établissements d'enseignement et de recherche français ou étrangers, des laboratoires publics ou privés. 


\title{
Multicriteria Decision Aid Tool for Third-Party Logistics Providers' Selection
}

\author{
Aicha Aguezzoul, Besoa Rabenasolo, Anne-Marie Jolly-Desodt \\ ENSAIT, 9 rue de l'Ermitage, BP 30329, 59056 Roubaix Cedex 01, France. \\ (aicha.aguezzoul, anne-marie.jolly-desodt, besoa.rabenasolo@ensait.fr)
}

\begin{abstract}
The outsourcing of logistics activities has become a common practice by many companies, which implies an efficient choice of the Third-Party Logistics (3PLs) providers. A literature review on the 3PLs provider's selection problem shows that this selection is a very complex process which depends on several factors, which are often in conflict with one another, such as price, quality, service, location, technology, etc. This paper proposes a software tool using ELECTRE method for selecting the 3PLs providers. This tool incorporates various selection criteria and allows the user to introduce other criteria according to his needs. The application of our tool is demonstrated through an illustrative example.
\end{abstract}

Keyword: Third-party logistics, multicriteria, ELECTRE method.

\section{INTRODUCTION}

In today's business world, many companies focus on their core competencies and outsource their logistics functions to the profit of the Third Party Logistics (3PLs) providers. The ever-increasing interest in logistics outsourcing is supported by many factors such as globalization and deregulation, the trade-off between asset specificity and performance measurement, corporate restructuring, the need for additional space, changes in logistics management and labour issues, etc.

Over the last two decades, the 3PLs providers have become important Payers in many chains and industries because they take part in the cost reduction, the productivity profits and the improvement of the service quality of their customers. The use of 3PLs providers is done rather on the basis of impartation relation or with a strategic alliance and it generally covers several logistic functions.

Once the decision has been made to work with a 3PLs provider, the next decision is to determine which provider. Thus, the selection of an efficient and potential set of 3PLs providers who can meet the service requirements of the customer and with whom the customer can strengthen its relationships become a crucial decision. This decision is influenced by several factors such as price, services offered, location, technology, quality, etc.

Currently, with the additional requirements being placed on many industries to prove the transport and the storage conditions of shipment, there are a number of additional factors to be taken into account in the decision-making process of the 3PLs providers' selection.
This paper is one of the first to address this issue and presents a multicriteria tool which considers various criteria to be taken into account in this issue.

The ELECTRE method is used to classify the 3PLs providers from the best ones to the less important ones and according the selection criteria used.

To achieve this objective, we present in the first section, the 3PLs providers characteristics. In the second section, a review of literature on 3PLs providers' selection is examined. The third section gives a description of our study, followed by an interpretation of the results. We end with some conclusions and further research directions.

\section{Third Party Logistics providers}

A Third Party Logistics (3PLs) company is a private firm that provides logistics services under a contract to a primary manufacturer, vendor, or user of a product or service. It is called third-party because the logistics provider does not own the products but participates in the supply chain at points between the manufacturer and the user of a given product. The 3PLs providers can perform logistics functions of customer either completely or only in part $[1,2]$. Initially, the 3PLs providers were carriers, storage companies or forwarding agents. They currently diversified by offering various services and by ensuring various activities. The principal 3PLs providers have their own warehouses and transport fleets and their credits are often deployed throughout the world. Table 1 provides a complete list of activities that the buyer associated with the 3PLs providers [3]. These activities vary from very specific to very broad. 
Table 1. Activities of 3PLs providers

\begin{tabular}{|l|l|}
\hline $\begin{array}{l}\text { Logistics } \\
\text { function }\end{array}$ & Activities \\
\hline Transportation & $\begin{array}{l}\text { Shipping, forwarding, } \\
\text { (de)consolidation, contract delivery, } \\
\text { freight bill payment/audit, household } \\
\text { goods relocation, load tendering, } \\
\text { brokering. }\end{array}$ \\
\hline Warehousing & $\begin{array}{l}\text { Storage, receiving, assembly, return } \\
\text { goods, marking/labelling, kitting. }\end{array}$ \\
\hline $\begin{array}{l}\text { Inventory } \\
\text { management }\end{array}$ & $\begin{array}{l}\text { Forecasting, location analysis, } \\
\text { network consulting, slotting/layout } \\
\text { design. }\end{array}$ \\
\hline Order processing & $\begin{array}{l}\text { Order entry/fulfilment, consignee } \\
\text { management, call centre. }\end{array}$ \\
\hline $\begin{array}{l}\text { Information } \\
\text { systems }\end{array}$ & $\begin{array}{l}\text { EDI/VANS, routeing/scheduling, } \\
\text { artificial intelligence, expert } \\
\text { systems, RFID, web-based } \\
\text { connectivity, tracking and tracing. }\end{array}$ \\
\hline Packaging & Design and recycling. \\
\hline
\end{tabular}

\section{REVIEW OF LITERATURE}

Sink et al. [3] conducted a survey in USA to investigate buyer perceptions of 3PLs services. Their findings are presented in five propositions: 3PLs markets in USA are growing and expanding rapidly, multiple reasons explain US buyers' interest in contract logistics, 3PLs solutions must be tailored to a customer's specific needs, core competences and focused capabilities eclipse the "one-stop shopping" concept when selecting a 3PLs provider and suppliers must understand the 3PLs buying..

In [4], the author has presented the five steps involved in choosing an effective 3PLs provider and which are: making decision, developing criteria and objectives, the weeding out process, determining the top project and beginning the new partnership.

Moberg and Speh [5] study the process of selecting 3PLs providers in order to outsource warehousing. Their empirical survey in the US shows that the most important indicators for choosing a particular 3PLs provider are related to responding to service requests, general management and ethical issues. Criteria that seem to be less important are the risk affinity of 3PLs providers, information technology, company size and coverage.

Colson and Dorigo [6] present a software tool which allows selecting public warehouses. Their extensive list of decision criteria includes: storage surface and volume, dangerous items, possibility for temperature control, separation of storage areas, control for temperature humidity, ventilation, offices on site, geographical distance to highway connection, train, waterways, certification (ISO 9001/9002, SQAS, HACCP), opening hours, assistance with customs, use of technology such as RFID/Barcoding, modem connection, handling equipment (electric, gas and diesel/petrol forklifts) number and characteristics of docks.

In [7], the authors apply an Analytic Network Process (ANP) for the final selection of the 3PLs providers. This tool classifies the criteria in three levels. The first one contains strategic criteria, named determinants and which are: compatibility, cost, quality, and reputation. At the second level, the criteria which support the achievement of the upper-level determinants and which named dimensions are identified. These dimensions are long-term relationship, operational performance, financial performance and risk management. The third level criteria in ANP model are named as enablers. These enablers support their respective dimensions and have some interdependencies among themselves. The ANP method allows more systematic analysis contrary to AHP method.

The study conducted with several customers of 3PLs providers in 2003 by the International Warehouse Logistics Association (IWLA), which gathers more than 550 logistics companies of North America, shows the change in the selection criteria's rankings (see table 2).

Table 2. 3PLs providers' selection factors

\begin{tabular}{|l|l|l|l|}
\hline Factor & 2003 & 1999 & 1994 \\
\hline Price & 1 & 4 & 11 \\
\hline Reliability & 2 & 2 & 2 \\
\hline Service quality & 3 & 1 & 1 \\
\hline On-time performance & 4 & 3 & 3 \\
\hline Cost reduction & 5 & 6 & 14 \\
\hline Flexibility and & 6 & 5 & 7 \\
\hline Good communication & 7 & 10 & 4 \\
\hline Management quality & 8 & 7 & 8 \\
\hline Location & 9 & 12 & 13 \\
\hline Customise service & 10 & 13 & 9 \\
\hline Speed of service & 11 & 8 & 6 \\
\hline Order cycle time & 12 & 9 & 10 \\
\hline Easy to work with & 13 & 16 & 12 \\
\hline Customer support & 14 & 11 & 5 \\
\hline Vendor reputation & 15 & 15 & 15 \\
\hline Technical competence & 16 & 18 & 19 \\
\hline Special expertise & 17 & 14 & 16 \\
\hline Systems capabilities & 18 & 17 & 17 \\
\hline Variety of available & 19 & 20 & 20 \\
\hline Decreased labour & 20 & 23 & 22 \\
\hline Personal relationships & 21 & 19 & 18 \\
\hline Decreased asset & 22 & 22 & 23 \\
\hline Early notification of & 23 & 21 & 21 \\
\hline Increased competition & 24 & 24 & 24 \\
\hline Global capabilities & 25 & 25 & 25 \\
\hline & & & \\
\hline & 19 & 17 \\
\hline
\end{tabular}


In 1994 and 1999, this table shows that the top three determinants in selecting a 3PLs provider were service quality, reliability and on-time performance. By 2003, the price became the most important selection criterion. This change is mainly due to the increase of quality and the number of services offered by the 3PLs providers, while the cost of these services will continues to decrease.

\section{DESCRIPTION OF THE TOOL}

The tool proposed in this paper uses ELECTRE method to classify the 3PLs providers from the best one to the worst regarding a set of criteria. This method is aimed at problems that involve selection and aims to reduce the size of the non-dominated set by means of concordance and discordance indexes that measure the advantage and equal relative disadvantage to pair among the alternatives.

This ELECTRE method is well adapted to our problem where we meet extremely diverse quantitative and qualitative criteria that cannot be converted to a common unit.

This tool is programmed using Visual Basic software. The data on the 3PLs providers used in our system are publicly available from Internet sites and specialized magazines on these providers. The main 3PLs providers used are: ABX Logistics, DHL Solutions, EASYDIS, EXEL, FM Logistics, Geodis, Hays Logistique, Norbert Dentressangle, Premium Logistics, SED Logistique, Sernam, Sogeros, Tibbett \& Britten, and TNT Logistics

Other data are gathered by mail, phone or e-mail addressed to some managers of the companies operating in the textile-garment field. These managers are members registered in the directory of the ENSAIT $^{1}$ School and represent the levels rather high in their firms.

The table 3 below presents the different criteria selection used in our tool. These criteria are classified in main ones and for each one; there are various secondary criteria.
Table 3. Main and secondary criteria of the tool

\begin{tabular}{|c|c|}
\hline Main criteria & Secondary criteria \\
\hline Services price & $\begin{array}{l}\text { National transport cost, international } \\
\text { transport cost, storage cost. }\end{array}$ \\
\hline $\begin{array}{l}\text { Quality } \\
\text { control }\end{array}$ & $\begin{array}{l}\text { Logistics audit, TQM, ISO 9000, ISO } \\
\text { 9002, OHSAS } 18001 \text {, etc. }\end{array}$ \\
\hline $\begin{array}{l}\text { Geographic } \\
\text { cover }\end{array}$ & $\begin{array}{l}\text { World set up, national set up, countries } \\
\text { served }\end{array}$ \\
\hline Firm culture & $\begin{array}{l}\text { Alliance types, strategic groups (guide, } \\
\text { integrator with the chain, mediator, } \\
\text { compromise), 3Ps 'customers }\end{array}$ \\
\hline Firm size & $\begin{array}{l}\text { Sales turnover, manpower, warehouses } \\
\text { number, warehouses area, etc. }\end{array}$ \\
\hline $\begin{array}{l}\text { On-time } \\
\text { performance }\end{array}$ & Lead-time \\
\hline $\begin{array}{l}\text { The range of } \\
\text { services } \\
\text { offered }\end{array}$ & $\begin{array}{l}\text { Transport, storage, distribution, valued } \\
\text { services added (customization, co- } \\
\text { packing, co-manufacturing, inventory } \\
\text { for customer), services management } \\
\text { (reverse logistics, promotion and } \\
\text { collection management, consulting } \\
\text { supply management, flows } \\
\text { management), customers services (call } \\
\text { center, setting in ray, service after sale, } \\
\text { installation on site). }\end{array}$ \\
\hline $\begin{array}{l}\text { Computing } \\
\text { performance }\end{array}$ & $\begin{array}{l}\text { Internal solutions (WMS, GPS, ECR, } \\
\text { etc.), connexion with the customer (EDI, } \\
\text { Internet portals, etc.), tracking and } \\
\text { tracing. }\end{array}$ \\
\hline
\end{tabular}

The importance of each selection main criterion is evaluated from 0 (less important) to 10 (extremely important). For each main criterion, the user can choose the secondary criteria.

To illustrate this tool, we present below an example of application.

\section{NUMERICAL EXAMPE}

In this case study, we evaluate the fourteen 3PLs providers which will be identified by $\mathrm{P} 1 \ldots \mathrm{P} 14$.

Let us suppose that we want to select the best 3PLs providers according to three criteria: geographic coverage, quality control and services offered. With each one of these criteria, one associates respectively weights 5, 3 and 4. Moreover, the associated secondary criteria are:

- Geographic coverage: The 3PLs providers must have warehouses in France, can serve the Maghreb and East of Asia and must have warehouses in North of France and Paris departments.

- Quality control: TQM and logistics audit

- Range of services offered: International transit, intermodal transport, inventory control, just in time, cross-docking, co-packing, and reverse logistics.

\footnotetext{
${ }^{1}$ Ecole Nationale Supérieure des Arts et Industries Textiles, Roubaix, France.
} 
According to these criteria, the performance table given by the tool has the following form:

Table 4. Performance table

\begin{tabular}{|l|l|l|l|l|}
\hline Criteria & $\begin{array}{l}\text { Geographic } \\
\text { cover }\end{array}$ & $\begin{array}{l}\text { Services } \\
\text { offered }\end{array}$ & $\begin{array}{l}\text { Quality } \\
\text { control }\end{array}$ & $\begin{array}{l}\text { Weighted } \\
\text { sum }\end{array}$ \\
\hline Weight & 5 & 4 & 3 & 12 \\
\hline P1 & 3.2 & 3.71 & 0 & 30.84 \\
\hline P2 & 4.4 & 4.57 & 0 & 40.28 \\
\hline P3 & 0 & 4.57 & 5 & 33.28 \\
\hline P4 & 3.2 & 3.71 & 0 & 30.84 \\
\hline P5 & 3.2 & 6.29 & 0 & 41.16 \\
\hline P6 & 4.4 & 3.71 & 0 & 36.84 \\
\hline P7 & 3.2 & 5.43 & 0 & 37.72 \\
\hline P8 & 0 & 5.43 & 5 & 36.72 \\
\hline P9 & 3.2 & 4.57 & 0 & 34.28 \\
\hline P10 & 0 & 5.43 & 0 & 21.72 \\
\hline P11 & 0 & 4.57 & 5 & 33.28 \\
\hline P12 & 4.4 & 3.71 & 0 & 36.84 \\
\hline P13 & 0 & 4.57 & 0 & 18.28 \\
\hline P14 & 0 & 3.71 & 0 & 14.84 \\
\hline
\end{tabular}

The ELECTRE method also gives the tables (5 and 6) of concordance and discordance. The concordance $\mathrm{c}(\mathrm{P} i, \mathrm{P} j)$ is an asymetric index that measures the arguments over all the selection criteria which are in favour of the hypothesis " $\mathrm{P} i$ is at least as good as $\mathrm{P} j$ " (preference or indifference), while the discordance $\mathrm{d}(\mathrm{P} i, \mathrm{P} j)$ measures the hypothesis " $\mathrm{P} j$ is preferred to $\mathrm{P} i$ ". The two values are normalized between 0 and 1 .

Table 5. Table of concordance

\begin{tabular}{|l|l|l|l|l|l|l|l|l|l|l|l|l|l|l|}
\hline & P1 & P2 & P3 & P4 & P5 & P6 & P7 & P8 & P9 & P10 & P11 & P12 & P13 & P14 \\
\hline P1 & & 0.25 & 0.42 & 1 & 0.67 & 0.58 & 0.67 & 0.42 & 0.67 & 0.67 & 0.42 & 0.58 & 0.67 & 1 \\
\hline P2 & 1 & & 0.75 & 1 & 0.67 & 1 & 0.67 & 0.42 & 1 & 0.67 & 0.75 & 1 & 1 & 1 \\
\hline P3 & 0.58 & 0.58 & & 0.58 & 0.25 & 0.58 & 0.25 & 0.67 & 0.58 & 0.67 & 1 & 0.58 & 1 & 1 \\
\hline P4 & 1 & 0.25 & 0.42 & & 0.67 & 0.58 & 0.67 & 0.42 & 0.67 & 0.67 & 0.42 & 0.58 & 0.67 & 1 \\
\hline P5 & 1 & 0.58 & 0.75 & 1 & & 0.58 & 1 & 0.75 & 1 & 1 & 0.75 & 0.58 & 1 & 1 \\
\hline P6 & 1 & 0.67 & 0.42 & 1 & 0.67 & & 0.67 & 0.42 & 0.67 & 0.67 & 0.42 & 1 & 0.67 & 1 \\
\hline P7 & 1 & 0.58 & 0.75 & 1 & 0.67 & 0.58 & & 0.75 & 1 & 1 & 0.75 & 0.58 & 1 & 1 \\
\hline P8 & 0.58 & 0.58 & 1 & 0.58 & 0.25 & 0.58 & 0.58 & & 0.58 & 1 & 1 & 0.58 & 1 & 1 \\
\hline P9 & 1 & 0.58 & 0.75 & 1 & 0.67 & 0.58 & 0.67 & 0.42 & & 0.67 & 0.75 & 0.58 & 1 & 1 \\
\hline P10 & 0.58 & 0.58 & 0.75 & 0.58 & 0.25 & 0.58 & 0.58 & 0.75 & 0.58 & & 0.75 & 0.58 & 1 & 1 \\
\hline P11 & 0.58 & 0.58 & 1 & 0.58 & 0.25 & 0.58 & 0.25 & 0.67 & 0.58 & 0.67 & & 0.58 & 1 & 1 \\
\hline P12 & 1 & 0.67 & 0.42 & 1 & 0.67 & 1 & 0.67 & 0.42 & 0.67 & 0.67 & 0.42 & & 0.67 & 1 \\
\hline P13 & 0.58 & 0.58 & 0.75 & 0.58 & 0.25 & 0.58 & 0.25 & 0.42 & 0.58 & 0.67 & 0.75 & 0.58 & & 1 \\
\hline P14 & 0.58 & 0.25 & 0.42 & 0.58 & 0.25 & 0.58 & 0.25 & 0.42 & 0.25 & 0.67 & 0.42 & 0.58 & 0.67 & \\
\hline
\end{tabular}

Table 6. Table of discordance

\begin{tabular}{|l|l|l|l|l|l|l|l|l|l|l|l|l|l|l|}
\hline & P1 & P2 & P3 & P4 & P5 & P6 & P7 & P8 & P9 & P10 & P11 & P12 & P13 & P14 \\
\hline P1 & & 0.1 & 0.5 & 0 & 0.3 & 0.1 & 0.2 & 0.5 & 0.1 & 0.2 & 0.5 & 0.1 & 0.1 & 0 \\
\hline P2 & 0 & & 0.5 & 0 & 0.2 & 0 & 0.1 & 0.5 & 0 & 0.1 & 0.5 & 0 & 0 & 0 \\
\hline P3 & 0.3 & 0.4 & & 0.3 & 0.3 & 0.4 & 0.3 & 0.1 & 0.3 & 0.1 & 0 & 0.4 & 0 & 0 \\
\hline P4 & 0 & 0.1 & 0.5 & & 0.3 & 0.1 & 0.2 & 0.5 & 0.1 & 0.2 & 0.5 & 0.1 & 0.1 & 0 \\
\hline P5 & 0 & 0.1 & 0.5 & 0 & & 0.1 & 0 & 0.5 & 0 & 0 & 0.5 & 0.1 & 0 & 0 \\
\hline P6 & 0 & 0.1 & 0.5 & 0 & 0.3 & & 0.2 & 0.5 & 0.1 & 0.2 & 0.5 & 0 & 0.1 & 0 \\
\hline P7 & 0 & 0.1 & 0.5 & 0 & 0.1 & 0.1 & & 0.5 & 0 & 0 & 0.5 & 0.1 & 0 & 0 \\
\hline P8 & 0.3 & 0.4 & 0 & 0.3 & 0.3 & 0.4 & 0.3 & & 0.3 & 0 & 0 & 0.4 & 0 & 0 \\
\hline P9 & 0 & 0.1 & 0.5 & 0 & 0.2 & 0.1 & 0.1 & 0.5 & & 0.1 & 0.5 & 0.1 & 0 & 0 \\
\hline P10 & 0.3 & 0.4 & 0.5 & 0.3 & 0.3 & 0.4 & 0.3 & 0.5 & 0.3 & & 0.5 & 0.4 & 0 & 0 \\
\hline P11 & 0.3 & 0.4 & 0 & 0.3 & 0.3 & 0.4 & 0.3 & 0.1 & 0.3 & 0.1 & & 0.4 & 0 & 0 \\
\hline P12 & 0 & 0.1 & 0.5 & 0 & 0.3 & 0 & 0.2 & 0.5 & 0.1 & 0.2 & 0.5 & & 0.1 & 0 \\
\hline P13 & 0.3 & 0.4 & 0.5 & 0.3 & 0.3 & 0.4 & 0.3 & 0.5 & 0.3 & 0.1 & 0.5 & 0.4 & & 0 \\
\hline P14 & 0.3 & 0.4 & 0.5 & 0.3 & 0.3 & 0.4 & 0.3 & 0.5 & 0.3 & 0.2 & 0.5 & 0.4 & 0.1 & \\
\hline
\end{tabular}

By fixing the thresholds of concordance and discordance at the respective values 0.8 and 0.1 , the final result is given in table 7 below: 
Table 7. Computational results

\begin{tabular}{|l|l|l|}
\hline Rank & 3Ps providers & Weighted sum \\
\hline 1 & P5 & 41.16 \\
\hline 2 & P2 & 40.28 \\
\hline 3 & P7 & 37.72 \\
\hline 4 & P6 & 36.84 \\
\hline 5 & P8 & 36.72 \\
\hline 6 & P12 & 36.84 \\
\hline 7 & P9 & 34.28 \\
\hline 8 & P3 & 33.28 \\
\hline 9 & P11 & 33.28 \\
\hline 10 & P1 & 30.84 \\
\hline 11 & P4 & 30.84 \\
\hline 12 & P10 & 21.72 \\
\hline 13 & P13 & 18.28 \\
\hline 14 & P14 & 14.84 \\
\hline
\end{tabular}

The tool gives the list of the 3PLs providers to select from the ELECTRE method as indicated by the greyed boxes in the table above. Those 3PLs providers are: P5, P2 and P8. We additionally compare this result with their classification according to their score obtained by the weighting method. Table 7 shows that the selection of P5 and P2 is consistent in the two methods, but the third-rated P7 and the fourth-rated P6 have not been selected by the ELECTRE method because they were dominated by the other 3PLs on some criteria which were not put in evidence with the weighted sum method.

\section{CONCLUSION}

This paper has presented a multicriteria decision aid tool for the 3PLs providers' selection. This tool use ELECTRE method, which makes it possible to classify these 3PLs providers. This allows the user to choose the 3PLs providers with whom he wants to work, by defining the importance of each of his own selection criteria.
This tool is also flexible enough to incorporate additional criteria, as required by the user, the competitive environment and organisational structure.

\section{REFERENCES}

[1] Delfmann W., Albers S., M. Gehring. "The impact of electronic commerce on logistics service providers", International Journal of Physical Distribution and Logistics Management, No. 32, pp 203-222, 2002.

[2] Lai K.H., Ngai E.W.T, T.C.E. Cheng. "An empirical study of supply chain performance in transport logistics". International Journal of Production Economics, No 87, pp 321-331, 2004.

[3] Sink H.L., Langley C. Jr, B.J. Gibson. "Buyer observations of the US third-party logistics market", International Journal of Physical Distribution Logistics Management, Vol. 26, No. 3, pp 8-46, 1996.

[4] S.M. Aghazadeh. "How to choose an effective third party logistics provider?", Management research news, Vol. 26, No. 7, pp 50-57, 2003.

[5] Moberg C.R., T.W Speh. "Third party warehousing selection: A comparison of national and regional firms", Distribution Centers of America.

[6] Colson G., F. Dorigo. "A public warehouse selection support system”, European Journal of Operational Research, Vol. 153, No.2, pp 332-349, 2004.

[7] Jharkharia S., R. Shankar. "Selection of logistics service provider: An analytic network process (ANP) approach", OMEGA: The International Journal of Management Science, 2005. 